\title{
Correction to: Global asthma prevalence in adults: findings from the cross-sectional world health survey
}

Teresa To ${ }^{1,2,3,9^{*}}$, Sanja Stanojevic ${ }^{1}$, Ginette Moores ${ }^{1,4}$, Andrea S. Gershon ${ }^{1,2,3,5}$, Eric D. Bateman ${ }^{6}$, Alvaro A. Cruz ${ }^{7}$ and Louis-Philippe Boulet ${ }^{8}$

\section{Correction to: BMC Public Health 12, 204 (2012)}

https://doi.org/10.1186/1471-2458-12-204

This article [1] has been corrected to acknowledge that Figs. 1 and 2 have been reproduced with permission of the $\odot$ ERS 2021: European Respiratory Journal Feb 2010, 35 (2) 279-286; DOI: 10.1183/09031936.00027509

\footnotetext{
Author details

${ }^{1}$ Child Health Evaluative Sciences, The Hospital for Sick Children, Toronto, Ontario, Canada. ${ }^{2}$ University of Toronto, Toronto, Ontario, Canada. ${ }^{3}$ The Institute for Clinical Evaluative Sciences, Toronto, Ontario, Canada. ${ }^{4}$ McMaster University, Hamilton, Ontario, Canada. ${ }^{5}$ Sunnybrook Health Sciences Centre, Toronto, Ontario, Canada. ${ }^{6}$ University of Cape Town, Cape Town, South Africa. ${ }^{7}$ ProAR - Núcleo de ExcelênciaemAsma, Faculdade de Medicina da Bahia, UFBA, Salvador, Brazil. ${ }^{8}$ Laval University, Quebec City, Quebec, Canada. ${ }^{9}$ Child Health Evaluative Sciences, The Hospital for Sick Children, 555 University Avenue, Toronto, Ontario M5G 1X8, Canada.
}

Published online: 08 October 2021

\section{Reference}

1. To, et al. Global asthma prevalence in adults: findings from the crosssectional world health survey. BMC Public Health. 2012;12:204. https://doi. org/10.1186/1471-2458-12-204

\footnotetext{
The original article can be found online at https://doi.org/10.1186/1471-245812-204.

* Correspondence: teresa.to@sickkids.ca

'Child Health Evaluative Sciences, The Hospital for Sick Children, Toronto,

Ontario, Canada

University of Toronto, Toronto, Ontario, Canada

Full list of author information is available at the end of the article
}

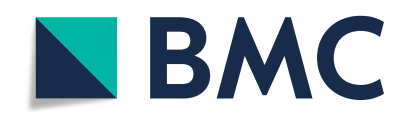

() The Author(s). 2021 Open Access This article is licensed under a Creative Commons Attribution 4.0 International License, which permits use, sharing, adaptation, distribution and reproduction in any medium or format, as long as you give appropriate credit to the original author(s) and the source, provide a link to the Creative Commons licence, and indicate if changes were made. The images or other third party material in this article are included in the article's Creative Commons licence, unless indicated otherwise in a credit line to the material. If material is not included in the article's Creative Commons licence and your intended use is not permitted by statutory regulation or exceeds the permitted use, you will need to obtain permission directly from the copyright holder. To view a copy of this licence, visit http://creativecommons.org/licenses/by/4.0/. The Creative Commons Public Domain Dedication waiver (http://creativecommons.org/publicdomain/zero/1.0/) applies to the data made available in this article, unless otherwise stated in a credit line to the data. 